\title{
Differences and Integration of Consumer Cultures between China and Western Countries and their Impact on the Recovery of Ethnic and Rural Areas
}

\author{
Shi Yan \\ Hangzhou Normal University
}

Follow this and additional works at: https://docs.lib.purdue.edu/clcweb

Part of the Asian Studies Commons

Dedicated to the dissemination of scholarly and professional information, Purdue University Press selects, develops, and distributes quality resources in several key subject areas for which its parent university is famous, including business, technology, health, veterinary medicine, and other selected disciplines in the humanities and sciences.

CLCWeb: Comparative Literature and Culture, the peer-reviewed, full-text, and open-access learned journal in the humanities and social sciences, publishes new scholarship following tenets of the discipline of comparative literature and the field of cultural studies designated as "comparative cultural studies." Publications in the journal are indexed in the Annual Bibliography of English Language and Literature (Chadwyck-Healey), the Arts and Humanities Citation Index (Thomson Reuters ISI), the Humanities Index (Wilson), Humanities International Complete (EBSCO), the International Bibliography of the Modern Language Association of America, and Scopus (Elsevier). The journal is affiliated with the Purdue University Press monograph series of Books in Comparative Cultural Studies. Contact: <clcweb@purdue.edu>

\section{Recommended Citation}

Yan, Shi. "Differences and Integration of Consumer Cultures between China and Western Countries and their Impact on the Recovery of Ethnic and Rural Areas." CLCWeb: Comparative Literature and Culture 20.2 (2018):

<https://doi.org/10.7771/1481-4374.3228>

This text has been double-blind peer reviewed by $2+1$ experts in the field.

The above text, published by Purdue University Press @Purdue University, has been downloaded 260 times as of $11 /$ $07 / 19$.

This document has been made available through Purdue e-Pubs, a service of the Purdue University Libraries. Please contact epubs@purdue.edu for additional information.

This is an Open Access journal. This means that it uses a funding model that does not charge readers or their institutions for access. Readers may freely read, download, copy, distribute, print, search, or link to the full texts of articles. This journal is covered under the CC BY-NC-ND license. 


\section{PURDUE}

U N I V ER R I T Y UNIVERSITY PRESS <http://www.thepress.purdue.edu>

\section{CLCWeb: Comparative Literature and Culture}

ISSN 1481-4374 <http://docs.lib.purdue.edu/clcweb> Purdue University Press @Purdue University

CLCWeb: Comparative Literature and Culture, the peer-reviewed, full-text, and open-access learned journal in the humanities and social sciences, publishes new scholarship following tenets of the discipline of comparative literature and the field of cultural studies designated as "comparative cultural studies." In addition to the publication of articles, the journal publishes review articles of scholarly books and publishes research material in its Library Series. Publications in the journal are indexed in the Annual Bibliography of English Language and Literature (Chadwyck-Healey), the Arts and Humanities Citation Index (Thomson Reuters ISI), the Humanities Index (Wilson), Humanities International Complete (EBSCO), the International Bibliography of the Modern Language Association of America, and Scopus (Elsevier). The journal is affiliated with the Purdue University Press monograph series of Books in Comparative Cultural Studies. Contact: <clcweb@purdue.edu>

\section{Volume 20 Issue 2 (Month 2018) Article 9 Shi Yan, "Differences and Integration of Consumer Cultures between China and Western Countries and their Impact on the Recovery of Ethnic and Rural Areas" <http://docs.lib.purdue.edu/clcweb/vol20/iss2/9> \\ Contents of CLCWeb: Comparative Literature and Culture 20.2 (2018) Thematic Issue The One Asia Foundation and its Cooperation and Peace-Making Project \\ Ed. Asunción López-Varela Azcárate \\ <http://docs.lib.purdue.edu/clcweb/vol20/iss2/>}

Abstract: In his paper "Differences and Integration of Consumer Cultures between China and Western Countries and their Impact on the Recovery of Ethnic and Rural Areas" Shi Yan introduces the overall situation and characteristics of Chinese and western consumer culture under the background of Asian and global electronic commerce and socio-cultural integration. The paper analyzes conflicts and differences from the perspective of consumption habits and patterns, and studies the characteristics, existing problems and attitudes towards the integration of China and western consumer culture. The final part of the paper addresses the problems of the consumer cultural integration of ethnic and rural areas in China by means of the development of structures of cultural industries that might include new consumption patterns, helping in the development of these areas. 


\section{Shi YAN}

\section{Differences and Integration of Consumer Cultures between China and Western Countries and their Impact on the Recovery of Ethnic and Rural Areas}

Integration is the one of the main trends of world development today. Whether in Europe or in Asia, the actual impact of global connections is everywhere. In this context, the consumer culture of the western countries is spreading rapidly across the world. With the expansion of the Internet and new media and the rapid circulation of goods and services, cultures are capable of reaching all corners of the globe. However, the dominance of certain languages and cultures exert a far-reaching influence on people from very different backgrounds. Under this tide of global contacts, traditional consumer culture in China is being influenced by western consumer culture in many ways. Trends of both conflict and integration are emerging and, with them, opportunities for development.

Different ethnic groups and societies have different cultural patterns, each which has its own characteristics, value orientation and potential value consciousness. Therefore, in the study of crosscultural issues, researchers tend to use territorial aspects as well as ethnic differences, sometimes making up nations and nationalities. These variables are used to explain the differences among people's attitudes and behavior and reveal the value orientation of diverse human groups.

In her well-known book Patterns of Culture, Ruth Benedict indicated that cultural development is always a process of integration, where some cultural material is selected, absorbed, rationalized, standardized, institutionalized and strengthened, becoming part of the psycho-socio-logical and behavioral characteristics of a given group, and of its historical memory (Benedict 93-94). However, other cultural material is also abandoned, suppressed from memory records, and altogether eliminated from common archives, losing its overall significance and value. In time, these processes of cultural integration conform common ideals, behavioral patterns and, in the case of consumer culture, consumer styles, attitudes and value orientations. Thus, consumption can vary significantly among cultures, countries and nationalities.

Consumer culture has been defined as the spectrum of consumption choices and behaviors from a socio-cultural point of view. Because it denotes a social arrangement in which the relations between lived cultural and social resources come into contact, the field includes a number of theoretical perspectives that reflect the dynamic relationships between consumer actions, socio-cultural aspects, and the contextual marketplace. Consumer culture theory is built on the borderland between cultural studies, the study of markets and the exchange of material resources, as well as consumer behavior.

As such, it also involves semiotic aspects of how products are commercialized by means of building certain identities and group orientations through the images, slogans and other signs used in their advertising.

China's consumer culture has attracted worldwide attention in recent years because of its rapid development. The People's Republic of China, with its huge population and long cultural history, has an amazing consumption capacity. The characteristics of China's consumer culture show significant differences in many aspects not only with western consumer cultures, but also with other Asian 
Shi Yan, "Conflict and Integration of Consumer Cultures between

China and Western Countries and their Impact on the Recovery of Ethnic and Rural Areas"

CLCWeb: Comparative Literature and Culture 20.2 (2018): <http://docs.lib.purdue.edu/clcweb/vol20/iss2/9>

Thematic Issue The One Asia Foundation and its Cooperation and Peace-Making Project. Ed. Asunción López-Varela Azcárate

countries such as Japan or South Korea. But very importantly, western culture is having a great impact on the process of the development of China's consumer culture.

Collisions are inevitably taking place between modern consumption culture, coming from the west, based on a stronger sense of individual identity, and China's traditional consumer culture, which follows Confucian and collectivist models of lack of self-display (Zou and Wang 14). There is also an ideological gap the two, as well as a huge level of influence of western consumer forms upon traditional Chinese consumerism. China faces an incapacity to discriminate and criticize western forms coming into the country, and among the young there is even a tendency to give greater validation to anything coming from the west. This has led to various forms of cultural fractures, with consumerism disintegrating the traditional culture and values of the People's Republic of China.

Consumer culture has a great impact on the economic operation and capital flows taking place in communities and countries. In her book Consumer Culture, British scholar Celia Lury explores the topic from the perspective of cultural sociology, indicating that it is a particular form of material culture that appeared in European and American societies in late $20^{\text {th }}$ century. Similarly Fredric Jameson, in his article The Cultural Logic of Late Capitalism, explains how capitalism reaches far beyond the realms of the economic (Jameson 398). Thus, consumer culture should not be understood as a substance related to use value, but as having a meaning related with symbolic value (Lury 1 ). Culture manifests itself and is influenced by objects, which should be viewed as semiotic carriers of meaning. Celia Lury also explains the changed perception of objects which, through advertising, have become loaded with new meanings, coming to signify something beyond their actual value in daily use. In order to highlight how consumer rate consumer goods, Lory discusses the relations of capital, class and consumer culture in the UK after World War II, addressing the impact of particular social groups (i.e. gender) as they are targeted by marketing programs, addressed to guide and direct consumer choice. Lory's final chapter provides examples, taken from daily life, of possible ways to identify consumer types, showing how consumption comes to be used as a way of strengthening the identity and exclusivity of certain social groups, moving beyond the economic impact of consumption to its sociological implications on lifestyle.

Mike Featherstone was one of the first to work on this topic and show that consumer culture not only referred to cultural products as commodities, improved in production. He pointed out that most cultural activities and ideographic practices are based on consumption and that mechanization and marketing brought consumption to become more and more a semiotic practice, where different signs (icons/images, symbols, and so on, following Charles S. Peirce's classification) are exchanged (Featherstone 161). From this semiotic perspective, consumer culture has the potential to reshape the cultural climate and consumer habits of a given nation.

Consumer culture can be divided into three aspects: consumption concept, consumption habit and consumption mode. Consumption concept is described as the guiding ideology and attitude of how people treat their disposable income, including the value orientation of pursuit of goods, as well as an overall cognitive evaluation and value judgment to consumption objects. Consumer behavior and consumption processes and trends are also involved, depending on where and when consumers are 
Shi Yan, "Conflict and Integration of Consumer Cultures between

China and Western Countries and their Impact on the Recovery of Ethnic and Rural Areas"

CLCWeb: Comparative Literature and Culture 20.2 (2018): <http://docs.lib.purdue.edu/clcweb/vol20/iss2/9>

Thematic Issue The One Asia Foundation and its Cooperation and Peace-Making Project. Ed. Asunción López-Varela Azcárate

ready for consumption activities. These aspects of the consumption concept are compatible with the development level of certain social productive forces and the level of socio-cultural development. For instance, with economic and social development, people have gradually abandoned traditional concepts of consumption such as self-sufficiency. Instead, the new concept of consumption is based on income and time-saving. In the case of consumer habits, these refer to their activities on the basis of certain social and material living conditions, as well as people's demands for certain type of goods or particular brands (Huang 68). Consumer behavior depends on social constraints and accumulates over time. Consumption patterns and modes refer to the combination of consumer and consumer materials under certain socio-economic conditions. It is related to the forms which consumers adopt and which have to do with their identity as part of given groups, communities and so on. These consumption patterns contribute to strengthen people's lifestyles and social relationships within the group. Thus, it can refer directly to consumers or to collective organizations (Guo 33).

Chinese scholar Yin Shijie directs his research to consumer education. He believes that consumer culture is not just about material wealth, but also about non-tangible aspects. To him, consumption is the sublimation and crystallization of cultural practice activities. For this reason, he places an emphasis on understanding its connotations as a cultural aspect, involving not just consumer goods, consumption modes and habits, but also the general atmosphere and conditions that may impact on all these aspects, and which can range from natural and environmental factors to customs and lifestyles, as well as affective aspects, all of which are related to particular communities in a certain place and at a given historical period. Thus, for a long time, consumer culture in the west has differed greatly from its Chinese counterpart.

Western consumer culture has been related to modernity, freedom of choice and individualism. The market has been the main determinant of consumer culture, and consumption was manifested as a privileged place of autonomy, endowed with meanings related to subjectivity, privacy and freedom. The consumption of commodities in the west is strongly tied to desire-inducing marketing mechanisms and the perpetuation of such system within the ideas of individual free personal choice prevalent in western countries, where cultural meanings are embodied in goods and products, acquiring particular roles in private and social situations. Prior to the $18^{\text {th }}$ century, the term 'property' was used mainly in reference to land ownership. With the rise of mercantilism there was a need to define 'private property' in a clearer way. One of the first to do so was English philosopher John Locke (1632-1704) who, in his Second Treatise on Government, claimed that any object can become the property of one person when the person's work efforts enter into the object. Locke started from the idea that all natural resources are common to all men, and that property comes about by the exertion of labor upon unowned resources. Locke defended individual property rights as something natural, following the same argument. It was in this way that gradually, the semiotic meanings of things, from natural resources to objects, became laden with the idea of something 'produced' by means of human labor. Thus, consumer culture conceptualizes an interconnected system of products, as well as their forms of representation (signs such as descriptive texts, images and so on) which convey socio-cultural identities, practices and meanings. 
Shi Yan, "Conflict and Integration of Consumer Cultures between

China and Western Countries and their Impact on the Recovery of Ethnic and Rural Areas"

CLCWeb: Comparative Literature and Culture 20.2 (2018): <http://docs.lib.purdue.edu/clcweb/vol20/iss2/9>

Thematic Issue The One Asia Foundation and its Cooperation and Peace-Making Project. Ed. Asunción López-Varela Azcárate

In his treaty The Protestant Ethic and the Spirit of Capitalism, German sociologist Max Weber (1864-1920) wrote that the capitalist marketplace in northern Europe had evolved from a particular Calvinist worldview which influenced large numbers of people to seek salvation by engaging in increasing productivity. Protestant ethics emphasized the importance of work as a way of redemption. However, it was this huge entrepreneurial force that lead to engage in ever growing forms of trade, colonialism, accumulation of resources, and later, with the institutionalization of banking, of wealth for investment. Weber wrote the original German text between 1904 and 1905, and it was translated into English in 1930 by North-American sociologist Talcott Parsons. The book became a founding text in economic sociology, explaining the emergence of uncoordinated 'laissez-faire' capitalism.

It was under such ethical convictions that people in the west began to meet their socio-cultural needs (including religious views) through material consumption, coming to regard it as a measure of their standard of living and social status. This trend became accelerated in the $20^{\text {th }}$ century. No longer under ideological grounds, western consumption culture became prey to the impetus and inertia of production, marketing and advertising, and the use of products beyond their functional purpose, reaching the recreational and the aesthetic realm, impacting upon people's personal images and becoming an emblem of the lifestyles. People's labor depended more and more on production. With the aid of machines first, and media technologies since the 1990s, products are more cheaply produced, advertised and sold. Consumption has become more prosperous, but overproduction is becoming an environmental threat. To Chinese scholars, western consumption embodies symbol consumption, including diverse forms of individualism and difference (He Xiaoqin, 2010:60).

Symbol consumption has the function of distinguishing social stratum and consolidating social difference. As indicated, over time consumption no longer involves purely physiological needs. Nowadays, an important component of consumption has to do with the symbolic value of goods, beyond their use-value. In their consuming patterns, people pay more attention to motivational aspects in which consumption is used to strengthen their identity, either as individual persons or as members of a given group (status, age-group, fashion, and so on), including personality traits, selfexpression and self-awareness. Items such as dress, dietary preferences, home furnishing, automobile, or entertainment, are chosen by the consumers according to their taste, personality and style. Western consumers also pursue aesthetic aspects, which in modern society is an important basis for social stratification and segmentation, which has become increasingly refined in postfordian societies (Bourdieu 228). Products are designed to meet the consumer's personalized demands, resulting in a decline in the degree of consumption consistency between different classes. At the same time, with the development of modern media, all kinds of information in advertisements lure people to make diversified consumption choices. Therefore, the promotion of different technological competences, the acceleration of market differentiation, the diversity of products and consumer awareness of this diversification have actively promoted a particularized consumer culture where people use consumption to stress their differences with others (Featherstone 166-167).

Finally, from the beginning of the 1990s, green consumer culture has also become very popular in the west. It corresponds to green consumption concepts and patterns such as green food, eco fashion, 
Shi Yan, "Conflict and Integration of Consumer Cultures between

China and Western Countries and their Impact on the Recovery of Ethnic and Rural Areas"

CLCWeb: Comparative Literature and Culture 20.2 (2018): <http://docs.lib.purdue.edu/clcweb/vol20/iss2/9>

Thematic Issue The One Asia Foundation and its Cooperation and Peace-Making Project. Ed. Asunción López-Varela Azcárate

green refrigerators, green cars, ecological housing, ecological gifts, eco-tourism, and so on. At the same time, the concept of moderate consumption, circular consumption and sustainable consumption has appeared all over the world. Green consumption advocates health, thrift and environmental protection of consumption. To this end, measures taken by the western countries include: the recovery and development of public transport, which not only reduces traffic jams, but especially reduces carbon emissions; the establishment of peer to peer support network in community energy planning; selecting appropriate agricultural food programs, or promoting worker-owner cooperatives, among others (Cohen 46). In order to establish new business models, such as "mindful spending" and "collaborative consumption" (Botsman and Rogers 125), the former is intended to help consumers make consumption budget and planning to reduce unnecessary expenditure, and the latter is designed to reduce intermediate links, lower commodity prices, and cost savings through consumer cooperation.

With regards to China, generally speaking, Chinese consumer culture has been conservative, and western consumer culture has been more open. Normally, the conservatism of Chinese consumer culture has been mainly reflected in the fact that consumption was directed to meet basic needs. The practical value and the price of products were the main basis for Chinese consumers to make purchase decisions. On the other hand, the openness of western consumer culture has been embodied in the pursuit of having more material goods, replacing products, or purchasing new and more up-to-date and fashionable ones. In western consumer culture, the replacement rate of purchased products has been higher, and the consumption concept, consumption habits and consumption patterns have shown greater diversity. People are more willing to spend money, whereas in China people were trying to save more.

As with the west, the formation of consumer cultures in China has historical reasons. Chinese society has been in a semi closed state for a long time. A self-sufficient economy and an isolated feudal concept have given Chinese consumer culture characteristics of stability and satisfaction with the existing state of things. Western culture has a tradition of opening up, always actively seeking expansion, raw materials and new markets. Adventure and novelty are also deeply ingrained in western consumer culture. In his book Consumer Society: Myth and Structure, the French cultural theorist, Jean Baudrillard also indicated that wealthy people are no longer surrounded by people as they used to be. Now they are surrounded by things (Baudrillard 36).

In recent years, consumer culture in China is rapidly changing. Although Chinese urban consumers have been influenced by western consumption culture in recent years, the vast rural areas still follow traditional agricultural social consumption patterns. Agricultural society pays attention to production and accumulation, loathing consumption and waste, attaching importance to family (Confucian) ethics and despising any individual demands of ego-assertiveness or individual self-expression (Liu and Zhou 185). The Confucian emphasis on harmony, justice, filial piety and benevolence has been one of the most important sources of traditional consumer culture in China rural areas. However, since 1980s, with the disintegration of the traditional family and the rapid growth of the one-child family, the concept of 'clan' that was present in traditional Chinese groups has gradually faded. The rapid growth 
Shi Yan, "Conflict and Integration of Consumer Cultures between

China and Western Countries and their Impact on the Recovery of Ethnic and Rural Areas"

CLCWeb: Comparative Literature and Culture 20.2 (2018): <http://docs.lib.purdue.edu/clcweb/vol20/iss2/9>

Thematic Issue The One Asia Foundation and its Cooperation and Peace-Making Project. Ed. Asunción López-Varela Azcárate

of urban population, and the acceleration of social mobility, are other reasons contributing to the disappearance of traditional Chinese consumption customs, frugality, strong social class differences and forms of etiquette.

With the improvement of individual independent economic ability, and the enhancement of consumption autonomy, the traditional Chinese concept of frugality has gone stale. Other factors of change are the development of market economy and the rapid increase of purchasing power of the majority of Chinese people. Consumption as a means to judge self-worth and social identity are becoming increasingly significant in the social lives of average Chinese men and women.

The impact of western influence upon various aspects of Chinese lifestyle has also affected consumer culture. Contemporary Chinese consumer culture lacks discernment and criticism. Many people are beginning to place a sudden emphasis on individualism, rejecting traditional Chinese cultural forms. Western forms are quickly becoming integrated within Chinese society, leading to the fracture, and even disappearance, of its own particularities (Jiang 6-7). The main consumer groups are still in agreement with traditional consumption view, but they have a money worship tendency which is completely alien to Chinese culture. The consumption concept is also developing towards individuation and fashion.

China's current consumer culture embodies the following characteristics:

(1) Consumption Individualization: Chinese consumers are increasingly considering the unique characteristics of the commodities. In particular, if the products used can enhance their socioeconomic status. Personal and emotional preferences are seen to match forms of symbolic value, rather than material value and use value. In the process of purchasing goods or services, consumers are using personalized choices to strengthen their sense of superiority.

(2) Consumer branding: more and more Chinese consumers see value no longer limited to concrete material attributes but to interest levels and connotation of brand products, meeting not only their practical needs, but also their intangible desires.

(3) Consumption culture is becoming more superficial, but also discontinuous and lacking in unity. The traditional Chinese culture of elegance and aestheticism attached to goods and products has become a mass culture where aesthetics and taste have been commodified and presented as daily necessities (Pan 25).

In this panorama of global socio-cultural transformation, new forms of Chinese consumer culture will emerge. But there is also a strong need to educate people to be intelligent consumers. Aspects such as social ethics and environmental concerns need to be brought to public awareness, particularly because China is the current producer of many of the products consumed everywhere in the world.

As indicated, there are many differences between Chinese and western consumers and consumer cultures. For example, in clothing consumption, Chinese consumers focus more on the external qualities, while western consumers prefer aspects of comfort. Very often, Chinese consumers prefer brands, while western ones focus on practicality. Shulian Zhou and Jie Wei Jie believe that the consumption concept is the core part of the consumer culture as value judgment, guiding ideology, behavior criterion, and tendency in the consumption process (Zhou and Wei 82). This is reflected in 
Shi Yan, "Conflict and Integration of Consumer Cultures between

China and Western Countries and their Impact on the Recovery of Ethnic and Rural Areas"

CLCWeb: Comparative Literature and Culture 20.2 (2018): <http://docs.lib.purdue.edu/clcweb/vol20/iss2/9>

Thematic Issue The One Asia Foundation and its Cooperation and Peace-Making Project. Ed. Asunción López-Varela Azcárate

the cultural levels and trends of material products, which might become stale and constraint consumer behavior.

There can be important differences between the consumption concept in China and in western countries. For instance, there are differences between the consumption concept of material and nonmaterial demands. In the case of China, traditional culture manifests itself mainly as terms of facevalue or prestige within a community and, consumption is directed in this regard. Chinese people will look down upon individuals who spend too much energy on entertainment, instead of making practical progress in their work and in their lives. In the West, because of the higher level of economic and social development of most countries, the consumption expenditure for culture, entertainment, sports and tourism is higher. Non-material consumption is relatively high in the west.

Another type of difference involves self-centered consumption concepts. The concept of "unrealistically comparison" among Chinese consumers has been largely restricted the subjectivity of consumption (Wu Xiaoyan 135). With the rapid development of Chinese economy, people are pursuing better lives, and the level of consumption has become a major manifestation of self-identity. People who wish to project an image of high face-value or prestige improve their consumption level, buy more and more advanced products. This is also so because consumption level is a symbol of status. In order to pursue higher social status, people must meet the consumption standard of the high-level group, resulting in a large number of consumer behavior oriented towards "unrealistically comparison." On the other hand, westerners are not so interested in the consumption of other people. In a sense, Westerners' self-centered consumption concept also greatly reduces people's economic pressures. Therefore, many western scholars believe that there is no contradiction between the level of consumption and economic laws.

China and the West also have diverse consumption habits. Chinese people pay more attention to tangible material consumption, practical and use value. They tend to disregard aesthetic value, although symbolic value is an important source of prestige within human groups in China. They simultaneously seek inexpensive, and durable consumer products. Fashion is not so important to them. Westerners, on the other hand, focus their attention towards material aspects, but also to aesthetics, and the pursuit of inner satisfaction. Intangible services involving leisure activities are more important in the west. For example, while Chinese would focus on quantity and quality of food, westerners will also find it important that the service standard is high, requiring nice settings, tableware, professional waiters and so on.

A consumption of subsistence is not uncommon in China, where the long periods of natural selfprovision economy have made people rely on themselves to meet all their living needs. This is particularly so in rural areas. In addition, from the perspective of public facilities and infrastructures, until very recently China consumption environments were relatively poor, and many leisure activities were confined to the family. Nowadays more and more Chinese people are able to engage in leisure, travel both within China and abroad, and seek forms of non-material consumption.

Finally, regarding monetary and credit consumption, Chinese consumers generally advocate a traditional way of life, saving money and resources in case of bad times. In 2013, China's personal 
Shi Yan, "Conflict and Integration of Consumer Cultures between

China and Western Countries and their Impact on the Recovery of Ethnic and Rural Areas"

CLCWeb: Comparative Literature and Culture 20.2 (2018): <http://docs.lib.purdue.edu/clcweb/vol20/iss2/9>

Thematic Issue The One Asia Foundation and its Cooperation and Peace-Making Project. Ed. Asunción López-Varela Azcárate

consumption credit accounted for only $18 \%$ of GDP, which was much lower than that of many developed countries in Asia. In contrast, credit consumption is widely practiced in the West. People not only buy houses and cars through credit, but they also use it to finance travel abroad, holidays and other intangible forms of consumption.

What are the challenges of economic globalization and how can consumer cultures become integrated in a fruitful way? The above lines have traced the general panorama of consumer cultures and their differences in China and the western world. However, with more and more consumer cultures having common features, absorbed and internalized by other groups of people, nations and territories in globalization, there is also a fear of how this internalization might affect people's lives, as well as the fear of local characteristics being suppressed, discarded and lost.

The integration of consumer cultures has certain positive significance for China. First of all, it can enrich the content of Chinese consumption culture, deepen the understanding and communication between China and Western countries, and provide conditions for China's presence to grow in the world as well. Secondly, the globalization of consumer culture also provides opportunities for China's excellent cultural products to enter the world. In addition, it provides some experience for the development of China's consumer culture (Zhou 64).

Among the changes taking place in Chinese consumer culture, we can mention more attention to individual choices in the process of consumption. This trend includes not only young people in pursuit of individual consumption but also elderly consumer groups. A statistical study by Peter Leeflang and Fred Van Raaij of the characteristics of consumer behavior in the European community showed that the aging groups showed similar consumer behavior to that of the young people. In China, the elderly are paying greater attention to health products, and they have more time to spend time shopping in malls and shopping centers. As living conditions improve, individuals also seek greater autonomy space, which they often dedicate to consumption (Leeflang and Van Raaij 380).

Besides this trend toward more personalized consumer choices, both Chinese and Western consumers have clearer pragmatic inclinations and they pursue material interests as well as intangible options. For example, in China many middle-class families are beginning to employ domestic help in order to extricate themselves from heavy housework and devote more time to work or to leisure.

In addition, Chinese and Western consumers alike have become more rational, seeking a good balance in their spending budget. The widespread use of the Internet allows consumers to compare prices online easily and quickly, both at home and abroad. More and more consumer choices are directed towards achieving a good balance between quality and price, although the search for the lowest possible price within the same range of products has become an important motivation in online consumer behavior.

In the process of global economic integration, Chinese and Western consumers are more likely to have a common consumer concept preference. Consumers pay more attention to environmental protection, healthy and rational consumption. This common culture of consumption demand will further promote the development of economic integration. 
Shi Yan, "Conflict and Integration of Consumer Cultures between

China and Western Countries and their Impact on the Recovery of Ethnic and Rural Areas"

CLCWeb: Comparative Literature and Culture 20.2 (2018): <http://docs.lib.purdue.edu/clcweb/vol20/iss2/9>

Thematic Issue The One Asia Foundation and its Cooperation and Peace-Making Project. Ed. Asunción López-Varela Azcárate

However, as indicated above, the consumption concept of the west is penetrating China very quickly, becoming integrated and discarding old traditions. Under the impact of the western consumer culture, Chinese traditional consumption culture is suffering from an unprecedented penetration, shaking Chinese ideology and values, and creating deep contradictions in the society. As the income gap in China continues to expand between social classes, and particularly between urban and rural areas, the country blindly pursues western consumption patterns and copies western consumption culture.

China is economically divided into Eastern, northeastern, central and western regions. Due to different level of economic and cultural development in eastern and western regions of China, consumers pursue and imitate western consumption patterns differently. There are twelve provinces which belong to eastern region of China, including Beijing, Tianjin, Hebei, Shandong, Jiangsu, Shanghai, Zhejiang, Fujian, Guangdong and Hainan. The eastern region has a relatively fast economic development, and the GDP, per capita disposable income and per capita consumption expenses are higher than those in the western region, while the economic development of provinces in the western region is relatively backward, including Shaanxi, Sichuan, Yunnan, Guizhou, Guangxi, Gansu, Qinghai, Ningxia, Tibet, Xinjiang, Inner Mongolia and Chongqing. In 2016, the per capita disposable income of Chinese residents was $¥ 23,821$, and the per capita consumption expenses was $¥ 1,711.1$ (http://www.stats.gov.cn, Statistical bulletin of the People's Republic of China). The GDP of Guangdong province ranked first at $¥ 79512.05$ billion yuan, and the per capita disposable income of residents was $¥ 30,295.8$, and the per capita consumption expenses of the residents was $¥ 23,367$. (www.gdstats.gov.cn, Statistics Bulletin of Guangdong...); The GDP of Inner Mongolia Autonomous Region, which has the best economic development in the western region, was ranked 16 th at $¥$ $13,682.6$, and the per capita disposable income was $¥ 2,4127$, and the per capita consumption expenses of the residents was $¥ 18,072$. (<www.nmgtj.gov.cn> Statistics Bulletin of Inner Mongolia). Only from these two indexes of the per capita disposable income and per capita consumption expenses, the western regions emerge far less rich than the eastern regions in China. Naturally, this greatly influences consumer consumption patterns and consumer culture.

The per capita consumption expenses of eastern residents is higher, and most of the world's top multinational companies have branches in the eastern region, which causes eastern region consumers to have more convenient consumption conditions where they largely imitate western consumer culture. McDonald's, KFC, Starbucks, Adidas, Benz, BMW and other international brands are found everywhere in the eastern cities and even in the countryside. Eating steak, drinking red wine, going to the gym after work, and similar western consumption patterns are increasingly accepted by consumers there.

In many parts of the western region, especially in low-income rural areas, consumers do not have enough to spend on high-end consumption after meeting their basic needs. However, Phillip Brown, Erwin Bulte and Xiaobo Zhang found that in China's rural poor areas, after meeting basic needs, residents, even those with lowest incomes, will not spend the rest of their income on education or 
Shi Yan, "Conflict and Integration of Consumer Cultures between

China and Western Countries and their Impact on the Recovery of Ethnic and Rural Areas"

CLCWeb: Comparative Literature and Culture 20.2 (2018): <http://docs.lib.purdue.edu/clcweb/vol20/iss2/9>

Thematic Issue The One Asia Foundation and its Cooperation and Peace-Making Project. Ed. Asunción López-Varela Azcárate

health, but on conspicuous consumption, such as weddings, funerals and collective activities (Brown, Bulte and Zhang 140).

The development of cultural industry often leads to a significant increase in the income of residents, as well as the optimization of consumption patterns and structure. According to the relationship between production and consumption, and between industrial structure and consumption, studies show that cultural industries are very important in China (Wu Shilei 116). They can increase residents' consumption, potential consumers, and help improve consumption patterns.

In the context of global economic integration and cultural integration, the consumer culture of Chinese rural residents has promoted a vigorous development of cultural industries. Take Inner Mongolia Autonomous Region as an example; in recent years, the added value of cultural industries growth rate reached $22 \%$, higher than the GDP growth, $12 \%$ in the same period. It reached $¥ 52.55$ billion in 2016, when the share of GDP rose to $2.82 \%$ (<http://lib.cet.com.cn> "Inner Mongolia"). Cultural industries are constantly expanding, their market growing, and consumption level rising. These factors are leading to changes in consumer patterns and diversified consumption in Inner Mongolia. Thus, the consumption patterns of rural residents in Inner Mongolia has shifted from basic subsistence consumption to development consumption in 2016. The per capita disposable income of rural residents was 11,609, an increase of $7.7 \%$ over the previous year, and the per capita consumption of rural areas was 11,463 , up by $7.8 \%$. Engel coefficient per family was $29.3 \%$ (<www.nmgtj.gov.cn> Statistics Bulletin) Along with the rapid development of the economy and the cultural industry in Inner Mongolia, consumption patterns have obvious changed. High quality consumption has been continuously on the increase; this includes transportation, communication, education, entertainment, life supplies and service, including tuition and miscellaneous expenses, books, newspapers, magazines movies, travel, etc.

The choice of material consumption by rural residents in Inner Mongolia is mainly concerned with practicality. With the improvement of economic development and the vigorous development of cultural industries, it is easier for villagers to travel and learn from the cities. For instance, rural residents have colored lights installed in the eaves of their homes to create a good atmosphere during festive seasons. Residents are not concerned with their practical use, but function as a symbol of family wellbeing and image, showing the changing patterns of consumer culture in rural areas.

Modern consumption culture has increasingly penetrated the daily lives of rural residents, and this is reflected in aspects such as the consumption of vehicles and family luxury goods. Besides, western influence is not contemplated as a cultural crisis. On the contrary. For instance, in the daily life of rural residents in Inner Mongolia, the consumption concept of western ecological protection is being integrated into the traditional Chinese consumer culture. Lei $\mathrm{Xu}$ found that white trash outside houses in the villages is now less visible. In general, rural dwellers have less waste, and they deal with nonrecyclable rubbish by burning it when cooking or putting into the biogas digester (Xu 31-32). This reduces grassland destruction maintaining the ecology of the environment. Nowadays, villages in some areas have implemented the use of biogas. The consumption of ecological energy is also reflected in the fact that the rural residents seldom use industrial chemical fertilizers and replace them 
with ecological fertilizers. In some of these areas, the traditional field gathering and hunting is still one auxiliary way of life consumption ways for rural residents, but at the same time of consumption, rural residents pay much attention to the sustainable development of ecological resources. Rural residents hate and abhor the behavior of not protecting the ecological environment and destroying the living habitat of wild animals and plants. They have started to advocate and pursue sustainable ecological consumption patterns.

To conclude this paper, under contemporary globalizing trends, it is very difficult to force Chinese consumption culture to maintain independence from the west. And although some experts believe that this trend might inevitably bring bad effects on China's economic, cultural and social construction, it is also argued that if a country wants to truly maintain the independence of consumer culture and develop a healthy way of consumer culture, it should strengthen its consumer culture competitiveness through opening up and integrating into the tide of globalization. It is also defended that the independence of national consumer culture and the globalization tide of consumer culture are not antagonistic trends, once homogenization is kept at bail. Experts argue that it will be positive to draw on the advanced ideas from western consumer culture, where productive forces reflect not just basic consumption needs but also ideology. Accordingly, Chinese development level of productivity also needs to be further deepened (Jiang 8). Specifically, in terms of consumption habits, China can draw on the experience of aesthetic value from the west and learn from individuation and customizing consumption concepts that would promote greater variety of consumption patterns.

Chinese people are showing a spirit and mind of openness and tolerance in this regard. They believe that China not only has the ability of self-renewal and innovation, but also that it has the ability to accommodate and transform any penetrating heterogeneous culture. In the process of consumption culture exchange, Chinese people have the confidence to maintain and develop the national uniqueness of Chinese consumer culture. Such trends are also a manifestation of the confidence and pride of the Chinese nation.

Acknowledgments: This research is Supported By Program for Young Talents of Science and Technology in Universities of Inner Mongolia Autonomous Region (NJYT-18-A16).

\section{Works Cited}

Baudrillard, Jean. The Consumer Society: Myths and Structures. Sage Publications, 1998.

Benedict, Ruth. Patterns of Culture. London: Routledge \& Keagan, 1934.

Bourdieu, Pierre. Distinction: A Social Critique of the Judgment of Taste. Cambridge: Harvard UP 1984.

Botsman, Rachel and Roo Rogers. What's Mime Is Yours: the Rise of Collaborative Consumption. New York; Harper Business, 2010.

Brown Phillip, Bulte Erwin, Zhang Xiaobo. "Positional Spending and Status Seeking in Rural China." Journal of Development Economics 96.1 (2011): 140.

China Economic Times (中国经济时报).内蒙古: 把文化产业打造成支柱产业(Inner Mongolia: Making Cultural Industry a Pillar Industry) October 26. 2017. <http://lib.cet.com.cn/paper/szb_con/494687.html>

China National Bureau of Statistics. 中华人民共和国 2016 年国民经济和社会发展统计公报 (Statistical bulletin of the People's Republic of China on national economic and social development 2016). <http://www.stats.gov.cn/tjsj/zxfb/201702/t20170228_1467424.html>.

Cohen, Mauric. "Collective Dissonance and the Transition to Post consumerism." Futures 52 (2013): 42-51.

Featherstone, Mike. Consumer culture and postmodernism. Sage Publications, 1991.

Guangdong Stats 中国广东省统计局 2016 年广东国民经济和社会发展统计公报 (Statistics Bulletin of Guangdong National Economic and Social Development of 2016).

<http://www.gdstats.gov.cn/tjzl/tjgb/201703/t20170308_358320.html>. 
Shi Yan, "Conflict and Integration of Consumer Cultures between

China and Western Countries and their Impact on the Recovery of Ethnic and Rural Areas"

CLCWeb: Comparative Literature and Culture 20.2 (2018): <http://docs.lib.purdue.edu/clcweb/vol20/iss2/9>

Thematic Issue The One Asia Foundation and its Cooperation and Peace-Making Project. Ed. Asunción López-Varela Azcárate

Guo, Jingpin (郭景萍). 生产消费文化和媒体消费文化 ("Production consumption culture and media consumption culture." Journal of Guangdong University of Business 3 (2002): 33-36.

$\mathrm{He}$, Xiaoqin (贺晓琴). 中西主流消费文化观念溯源及其比较 ("The Origin and Comparative Study on Mainstream of Chinese and Western Consumer Cultures"). Lanzhou UP, 2010, 59-61.

Huang, Mouchen (黄谋琛). 冲突与融合: 全球化时代的文化境遇 ("Conflict and Integration: the Cultural Situation in the Age of Globalization." Learning Forum 3 (2013): 66-70.

Jameson Fredric. Postmodernism, or, the cultural logic of late capitalism. Durham: Duke UP, 1991.

Jiang，Jianguo（蒋建国）. 开放、多元与主体重塑: 当代中国消费文化的路向 ("Open, Pluralistic and Main Body Remodeling: the Direction of Contemporary Chinese Consumer culture"). Guizhou Social Science (2012): 4-9.

Leeflang, Peter and Fred Van Raaij. "The Changing Consumer in the European Union: A 'meta-analysis.'" International Journal of Research in Marketing, 12.5 (1995): 373-387.

Liu, Yang and Zhou Ying (刘洋, 周芗).基于生态文明观的中西消费文化比较与建设启示("Comparison and Construction Enlightenment of Chinese and Western Consumption Culture Based on Ecological Civilization View"). Journal of Shenyang University of Technology 4 (2016):184-188.

Lury, Celia. Consumer culture. New Brunswick: Rutgers UP, 1996.

Nmgtj 中国内蒙古自治区统计局 2016 年内蒙古自治区国民经济和社会发展统计公报 (Statistics Bulletin of Inner Mongolia National Economic and Social Development of 2016.

<http://www.nmgtj.gov.cn/nmgttj/tjgb/jjshfztjgb/webinfo/2017/03/1485311366743303.html>.

Pan, Bin (潘斌). 后现代消费文化特征下的品牌塑造思考 ("Reflections on Brand Building under the Characteristics of Postmodern Consumption Culture"). Commercial Times 27 (2010): 21-27.

Wu, Shilei (吴石否). 中国文化产业发展对居民消费的影响研究. ("Effects of China's Culture Industry Development on Household Consumption" Northeast Normal University Journal (2014). 116.

Wu, Xiaoyan. "Consumer Culture Conflicts Caused by Scientific and Technological Risks and the Construction of Harmonious Culture." Theory and Reform 2 (2013):133-137.

Xu Lei (徐否)，民族地区农村消费文化变迁研究 ("Study On Rural Consumer Culture Changes In Minority Areas." Hubei University Journal of Nationalities. 2016.

Yin, Shijie (尹世杰). 加强对消费文化的研究 ("Strengthen the Study of Consumer Culture"). Guangming Daily. April 30， 1995.

Zhou, Xiaobing (周笑兵). 全球化背景下的民族消费文化 ("National Consumer Culture under the Background of Globalization"). Practice and Theory of SEZS 1 (2007): 61-64.

Zhou, Shulian and Wei, Jie (周淑莲, 魏杰). 如何加强对消费文化的研究和引导 ("How to Strengthen the Research and Guidance of Consumer Culture"). Consumer Economics 6 (2014): 79-84.

Zou, Guangwen and Wang Zongheng (邹广文, 王宗衡). 全球化时代的消费文化 ("The Consumer Culture of Globalized Age"). Decoration 9 (2008): 12-15.

Author's profile: Shi Yan teaches at the Management College, Inner Mongolia University of Technology, China. His interests in research include consumer behavior and cross-culture studies. Yan's publications include Crosscultural Symbolic Consumption and the Behavior of Chinese Consumers, Cultura. International Journal of Philosogy of Culture and Axiology (2007). E-mail: <stephen_ys@126.com> 